\title{
Training and Certification Programs on Industrial Energy Systems in the United States.
}

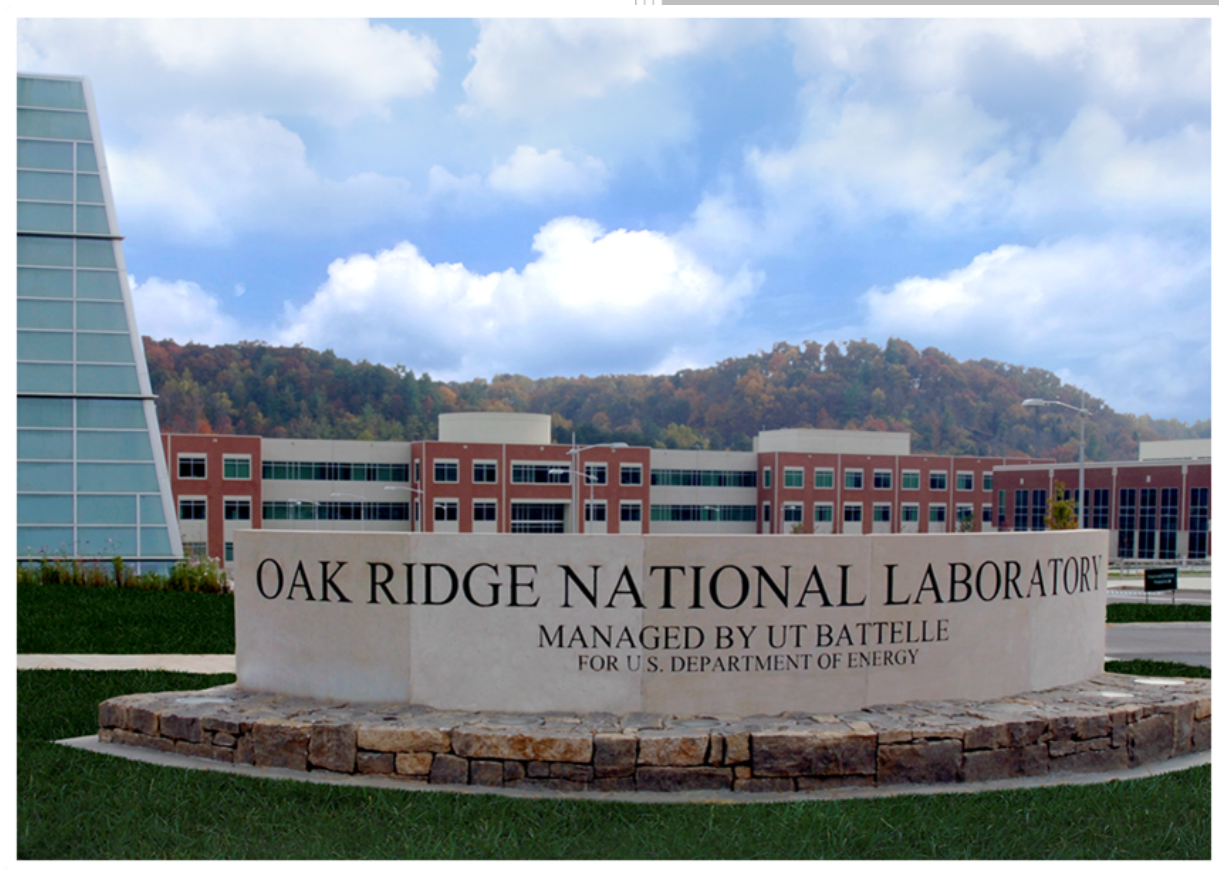

Wei Guo

Thomas Wenning Sachin Nimbalkar Daryl Cox Kiran Thirumaran Sandy Glatt January 2018 


\title{
DOCUMENT AVAILABILITY
}

Reports produced after January 1, 1996, are generally available free via US Department of Energy (DOE) SciTech Connect.

Website http://www.osti.gov/scitech/

Reports produced before January 1, 1996, may be purchased by members of the public from the following source:

\author{
National Technical Information Service \\ 5285 Port Royal Road \\ Springfield, VA 22161 \\ Telephone 703-605-6000 (1-800-553-6847) \\ TDD 703-487-4639 \\ Fax 703-605-6900 \\ E-mail info@ntis.gov \\ Website http://classic.ntis.gov/
}

Reports are available to DOE employees, DOE contractors, Energy Technology Data Exchange representatives, and International Nuclear Information System representatives from the following source:

Office of Scientific and Technical Information

PO Box 62

Oak Ridge, TN 37831

Telephone 865-576-8401

Fax 865-576-5728

E-mail reports@osti.gov

Website http://www.osti.gov/contact.html

This report was prepared as an account of work sponsored by an
agency of the United States Government. Neither the United States
Government nor any agency thereof, nor any of their employees, makes
any warranty, express or implied, or assumes any legal liability or
responsibility for the accuracy, completeness, or usefulness of any
information, apparatus, product, or process disclosed, or represents that
its use would not infringe privately owned rights. Reference herein to
any specific commercial product, process, or service by trade name,
trademark, manufacturer, or otherwise, does not necessarily constitute
or imply its endorsement, recommendation, or favoring by the United
States Government or any agency thereof. The views and opinions of
authors expressed herein do not necessarily state or reflect those of the
United States Government or any agency thereof.


Energy and Transportation Science Division

\title{
TRAINING AND CERTIFICATION PROGRAMS ON INDUSTRIAL ENERGY SYSTEMS IN THE UNITED STATES
}

\author{
Wei Guo (Oak Ridge National Laboratory) \\ Thomas Wenning (Oak Ridge National Laboratory) \\ Sachin Nimbalkar (Oak Ridge National Laboratory) \\ Daryl Cox (Oak Ridge National Laboratory) \\ Kiran Thirumaran (Oak Ridge National Laboratory) \\ Sandy Glatt (U.S. Department of Energy)
}

Date Published: January 2018

Prepared by

OAK RIDGE NATIONAL LABORATORY

Oak Ridge, TN 37831-6283

managed by

UT-BATTELLE, LLC

for the

US DEPARTMENT OF ENERGY

under contract DE-AC05-00OR22725 



\section{CONTENTS}

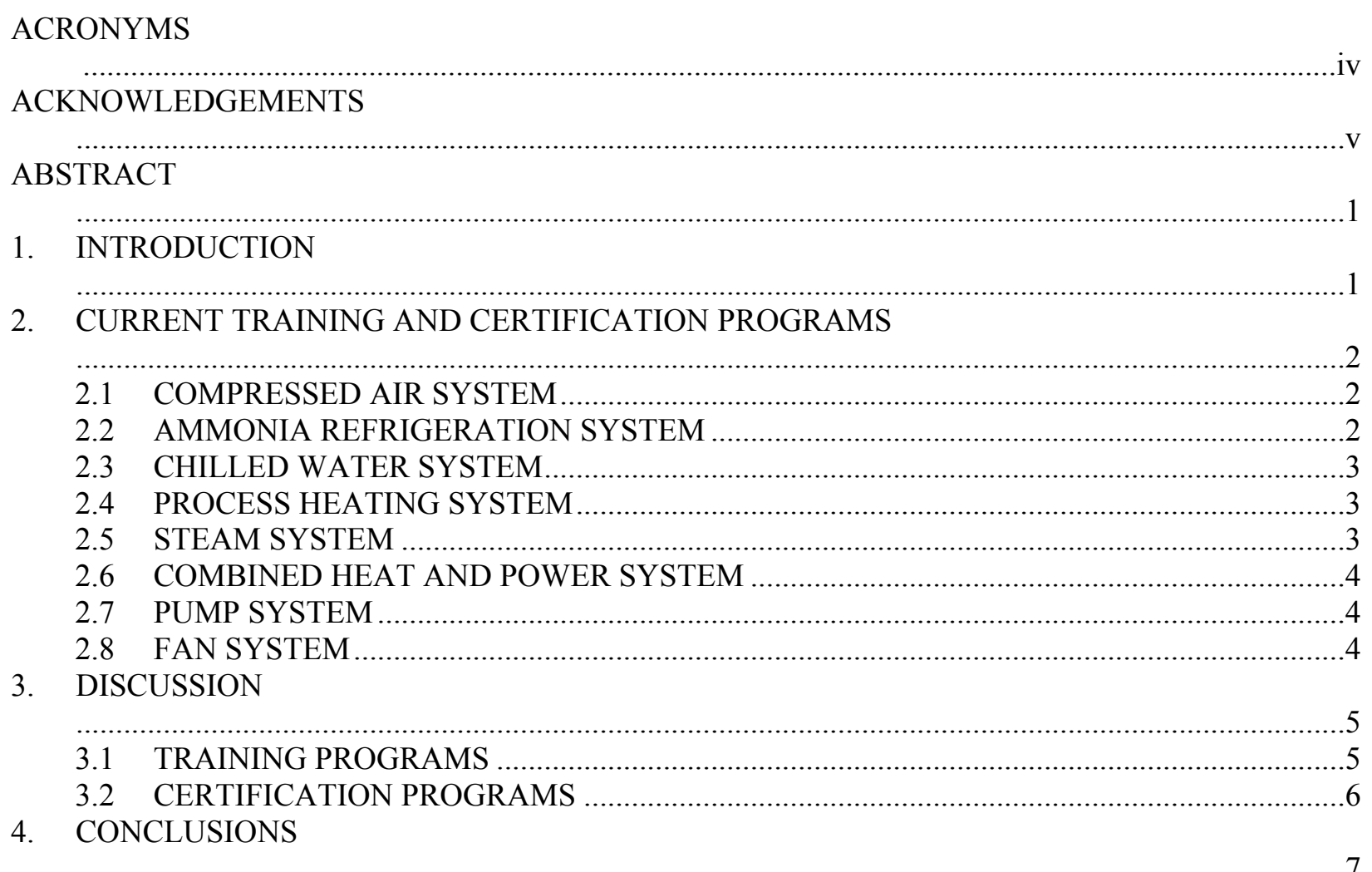




\section{ACRONYMS}

$\begin{array}{ll}\text { AEE } & \text { Association of Energy Engineers } \\ \text { ANSI } & \text { American National Standards Institute } \\ \text { ASHRAE } & \text { American Society of Heating, Refrigerating and Air-Conditioning Engineers } \\ \text { ASME } & \text { American Society of Mechanical Engineers } \\ \text { ATMT } & \text { American Trainco Maintenance Technician } \\ \text { CAC } & \text { Compressed Air Challenge } \\ \text { CAGI } & \text { Compressed Air and Gas Institute } \\ \text { CARO } & \text { Certified Assistant Refrigeration Operator } \\ \text { CHP } & \text { Combined Heat and Power } \\ \text { CIRO } & \text { Certified Industrial Refrigeration Operator } \\ \text { CRES } & \text { Certified Refrigeration Energy Specialist } \\ \text { DOE } & \text { US Department of Energy } \\ \text { GTI } & \text { Gas Technology Institute } \\ \text { HI } & \text { Hydraulic Institute } \\ \text { IEC } & \text { International Electrotechnical Commission } \\ \text { IHEA } & \text { Industrial Heating Equipment Association } \\ \text { IIAR } & \text { International Institute of Ammonia Refrigeration } \\ \text { ISO } & \text { International Organization for Standardization } \\ \text { PSAP } & \text { Pump System Assessment Professional } \\ \text { RAI } & \text { RETA Authorized Instructor } \\ \text { RETA } & \text { Refrigeration Engineers and Technicians Association }\end{array}$




\section{ACKNOWLEDGEMENTS}

The authors thank the Advanced Manufacturing Office of the US Department of Energy for support. We would also like to thank Mahabir Bhandari and Jennifer Travis, both of Oak Ridge National Laboratory, who assisted in the development and review of this report. However, the opinions expressed here do not necessarily reflect the policies of the sponsor. 


\begin{abstract}
The major industrial energy systems commonly found in manufacturing facilities are compressed air, ammonia refrigeration, chilled water, steam, process heating, combined heat and power, pumps, and fans. The efficiency of these systems contributes significantly to the whole-facility energy performance. On the national and even the international level, well-structured training and highly recognized certification programs help develop a highly skilled and qualified workforce to maintain and improve facilities' energy performance, particularly as technologies within these systems become more and more advanced. The purpose of this paper is to review currently available vendor-agnostic training and certification programs focusing on these systems and to identify the gap between market needs and currently available programs. Its three major conclusions are (1) most training programs focus on operations, maintenance, safety, and design although some briefly touch on energy performance aspects. (2) The Certified Refrigeration Energy Specialist certification by RETA the and Pump System Assessment Professional certification by HI were the only certifications found to be tool-agnostics and emphasize knowledge and skills for improving and maintaining systems energy performance. (3) Developing energy efficiency focused training and ANSI accredited certification programs for industrial energy systems will fill the gap between market needs and currently available programs.
\end{abstract}

\title{
1. INTRODUCTION
}

In the United States, industrial facilities accounted for about 32\% of the total national energy consumption in 2016. Improving the energy efficiency of industrial facilities benefits companies financially, mitigates energy-related business risks, and protects the environment by reducing greenhouse gas emissions. Major industrial energy systems commonly found in manufacturing facilities include compressed air, ammonia refrigeration, chilled water, steam, process heating, combined heat and power, pumps, and fans. The energy efficiency of these energy systems contributes significantly to the wholefacility energy performance.

Well-structured training programs enhance the attendees' understanding of working principles, knowledge of best practices, and capability to analyze the energy performance data of industrial energy systems. Training employees on these systems also helps create a safer working environment, increase employee's engagement and productivity, and improve system reliability and energy efficiency.

Certifications make the capabilities of industrial professionals more highly visible. Certification programs also motivate professionals to strategically improve their expertise and obtain new skill sets. In addition, highly credible certification programs provide employers with a reliable mechanism for evaluating the technical competence of candidates for positions and help them hire the right people.

On the national and even the international level, training and certification programs can help develop a highly skilled, better qualified workforce to improve and maintain industrial facility energy performance, particularly as technologies within these systems become more and more advanced. The following sections review currently available training and certification programs for industrial systems, identify the gaps between market needs and current programs, and propose some ways of filling the gaps. 


\section{CURRENT TRAINING AND CERTIFICATION PROGRAMS}

\subsection{COMPRESSED AIR SYSTEM}

The Compressed Air Challenge (CAC) and Compressed Air and Gas Institute (CAGI) are two major nonprofit trade associations that provide training. CAC currently offers four training programs: Fundamentals of Compressed Air Systems, Advanced Management of Compressed Air Systems, AIRMaster+ Specialist Qualification (in partnership with the US Department of Energy (DOE)), and "Compressed Air, It's Not Free!". CAGI's training program, called "Smart Site," is a series of eight online e-learning modules covering various aspects of compressed air system operation and maintenance. DOE offers hands-on and classroom training on compressed air system optimization through the Better Plants Program In-Plant Trainings.

Some air compressor system manufacturers and vendors provide training sessions to educate their clients on general compressed air system knowledge and their products and services. Typically, these training sessions can be tailored to meet clients' specific needs. Limited information was available regarding the details of the training content.

One online education provider, PDHonline.com, offers seven online courses for compressed air systems: Compressed Air Energy Storage, Compressed Air Systems, Introduction to Industrial Compressed Air Systems, Improving the Performance of Compressed Air Systems, Compressed Air Energy Efficiency, Air Compressors-Basic Concepts and Application, and Introduction to Compressed Air Systems. The detailed content of the courses is not accessible without registration for the courses.

Only one certification was found for compressed air systems - Qualified AIRMaster+ Specialist, which is offered by CAC and DOE. This certification recognizes candidates for their ability to use the AIRMaster+ software effectively with industrial end use equipment. Candidates for certification must pass an exam, which includes both written and practical components.

In summary, not including training provided by manufacturers or vendors, 12 training programs and courses were found. Only two online courses seemed designed to focus on the energy efficiency perspective of compressed air systems. The only certification found was Qualified AIRMaster+ Specialist, and it is not accredited by the American National Standards Institute (ANSI).

\subsection{AMMONIA REFRIGERATION SYSTEM}

Four community colleges (Garden City Community College, Lanier Technical College, Polk State College, and Industrial Refrigeration Technical College) and three engineering consulting/training firms (Nh3jobs Training, Industrial Consultants, and Envirosure Solutions) seem to be the major training providers. The training programs offered by these providers are mainly structured to help prepare participants to become ammonia system operators and energy specialists certified by the Refrigerating Engineers and Technicians Association (RETA). Most of the courses have both classroom and field training components. They include a basic introduction to industrial refrigeration systems, industrial refrigeration system operation, process hazards and safety, and energy efficiency.

The Department of Engineering Professional Development at the University of Wisconsin-Madison provides a set of courses covering the basics, principles, design, safety, and hazard analysis of industrial refrigeration systems. DOE offers hands-on and classroom training on ammonia refrigeration system optimization through the Better Plants Program In-Plant Trainings. 
Some manufacturers and vendors also provide training on refrigeration systems and their products. Limited information is available on the details of the training content.

RETA provides four certifications: Certified Assistant Refrigeration Operator (CARO), Certified Industrial Refrigeration Operator (CIRO), Certified Refrigeration Energy Specialist (CRES), and RETA Authorized Instructor (RAI). Note that CARO and CIRO are ANSI accredited, and candidates for these two certificates must pass exams with both written and practical components. CRES and RAI are not ANSI accredited.

The International Institute of Ammonia Refrigeration (IIAR) provides a certification for Safe Design of Closed-Circuit Ammonia Refrigeration Systems.

In summary, not including training provided by manufacturers or vendors, 48 training programs and courses were found. Three of those training programs focus on the energy efficiency of ammonia refrigeration systems. Five ammonia refrigeration system-related certifications were found, two of which are ANSI accredited. One of the five certifications is for energy efficiency; it is not ANSI accredited.

\subsection{CHILLED WATER SYSTEM}

The main providers of training in chilled water systems are ASHRAE (the American Society of Heating, Refrigerating and Air-Conditioning Engineers), the University of Wisconsin-Madison, Northwest Energy Efficiency Alliance, and a few training companies (e.g., NTT Training and TPC Trainco). Major chiller manufacturers also offer training. Most training programs are focused primarily on the design of chilled water systems.

Not including the training provided by manufacturers or vendors, 12 training programs were found, 2 of which (provided by Northwest Energy Efficiency Alliance) focus on energy efficiency. No chilled water system-related certifications - focused on either design, operation, or energy efficiency - were found.

\subsection{PROCESS HEATING SYSTEM}

The Industrial Heating Equipment Association (IHEA) and Gas Technology Institute (GTI) are the two major nonprofit trade associations that provide training in process heating. Two training programs provided by IHEA are focused on the fundamentals of process heating and the understanding of various industrial process heating technologies, whereas the two training courses provided by GTI concentrate more on the energy efficiency of new and existing process heating technologies. DOE offers hands-on and classroom training on process heating system optimization through the Better Plants Program In-Plant Trainings.

Numerous engineering consulting firms also provide training in process heating energy assessment and burner operation. Their websites offer limited detailed information regarding the content of the training.

Two certifications were found: Qualified Process Heating Assessment and Survey Tool Specialist, available but no longer actively offered by DOE, and Chartered Industrial Gas Consultant, offered by GTI.

\subsection{STEAM SYSTEM}

GTI has a 2-day course to provide an essential understanding of complex industrial steam generation and in-plant distribution. The American Society of Mechanical Engineers (ASME) has a 2-day course 
focusing on boiler operation and maintenance. DOE offers hands-on and classroom training on steam system optimization through the Better Plants Program In-Plant Trainings.

Numerous training programs are provided by steam system manufacturers and vendors of steam systems, and some of them focus on system optimization. However, the technical depth of those programs usually cannot be easily ascertained from the training information on their websites.

Only two certifications for steam systems were found: Qualified Steam System Assessment Tool Specialist, available but no longer actively offered by DOE, and ATMT Certified Qualified Boiler Operator, offered by TPC Trainco.

\subsection{COMBINED HEAT AND POWER SYSTEM}

The Association of Energy Engineers (AEE) and ASHRAE are the two-major combined heat and power (CHP) system training providers. These workshops mainly cover the design, operation, and maintenance of CHP systems. Three training programs were found, not including training provided by manufacturers or vendors.

The only CHP-related certification found is Distributed Generation Certified Professional training provided by AEE.

\subsection{PUMP SYSTEM}

Numerous pump training programs were found. Most of these programs are provided by pump manufacturers and vendors and focus on various aspects of pump systems: the basics of hydraulic systems, pump components (e.g., seals, drive, lubrication, vibration), installation, operation, and maintenance. DOE offers hands-on and classroom training on pump system optimization through the Better Plants Program In-Plant Trainings.

The only nonprofit trade association training provider found is Hydraulic Institute (HI). HI provides three major training programs: Pump Systems Assessment Certificate Training Program, Rotodynamic Pumps Certificate Training Program, and Positive Displacement Pumps Certificate Training Program.

HI currently offers the PSAP (Pump System Assessment Professional) certification. This certification is intended to be ANSI-accredited. DOE makes available a certification for Qualified Pumping System Assessment Tool Specialist but no longer actively offers it.

\subsection{FAN SYSTEM}

Like the case for pump systems, a large number of manufactures and vendors provide training programs for the installation, operation and maintenance of fan systems. DOE offers hands-on and classroom training on fan system optimization through the Better Plants Program In-Plant Trainings. One energy consulting firm was found to provide online courses focusing on fan system energy efficiency. No nonprofit trade association training providers for fan systems were found.

Only one certification for fan systems was found-Qualified Fan System Assessment Tool Specialist certification which is available but no longer actively offered by DOE. 


\section{DISCUSSION}

\subsection{TRAINING PROGRAMS}

It is apparent that there are many training programs related to each industrial energy system. Table 1 shows a number of training programs and courses provided by organizations other than manufacturer/vendor groups. The major providers of these training programs include nonprofit trade associations, equipment manufacturers and vendors, training companies, and universities. Typically, the content of the training sessions provided by equipment manufacturers and vendors can be tailored to meet their customers' specific needs and the requirements of their products.

Table 1. Number of Training Programs and Courses Provided by Organizations Other than Manufacturer/vendor Groups

\begin{tabular}{|c|c|c|}
\hline Energy systems & Total & $\begin{array}{c}\text { Focus on system } \\
\text { energy efficiency }\end{array}$ \\
\hline Compressed Air System & 12 & 4 \\
\hline Industrial Refrigeration System & 48 & 4 \\
\hline Chilled Water System & 12 & 2 \\
\hline Process Heating System & 5 & 5 \\
\hline Steam System & 2 & 2 \\
\hline Combine Heat and Power System & 3 & 0 \\
\hline Pump System Over & More than 50 & 5 \\
\hline Fan System Over & More than 50 & 3 \\
\hline
\end{tabular}

Not all training programs have both classroom and field hands-on training; some include only online courses. Most training programs focus on basic principles, operations, maintenance, safety, and design, although some programs also briefly discuss the energy performance aspects of these systems. Judging from their titles, a few training programs seem to focus on system energy efficiency; however, the technical depth of these training programs cannot easily be discerned from the training program web pages.

Section 4.5 of ISO 50001 2011, "Energy Management System-Requirements with Guidance for Use," requires that organizations provide training on the controls and operation of systems that are significant energy end users to improve facility energy efficiency. However, training programs focused on energy efficiency could not easily be found for some systems. Furthermore, for the training programs that were found, the limited information on the web pages made it difficult to determine whether the training programs accommodate system operators' technical backgrounds. Thus, there is a gap between the energy efficiency market needs and the current available training programs related to these energy systems.

Training programs that focus solely on energy efficiency with reasonable technical depth would be very beneficial for employees who have limited time, already have good knowledge of normal operation, and are willing to pursue more knowledge to improve the energy performance of industrial systems. These training programs can be designed to cover more complex and practical energy efficiency-related technical topics, but they do not have to last more than 5 work days. Topics could include key energy performance indicators, trending data points for energy performance tracking, energy performance data analysis, operational parameters that significantly affect energy performance, energy assessment procedures, best practices, implementation of common energy conservation measures, and innovative technologies. 
The topics or syllabi of training programs should be easily accessible so that trainees or employers can determine the value of the training sessions. Training programs could also be structured to increase the technical depth gradually to accommodate attendees with different technical backgrounds.

The ultimate purpose of training programs is to provide attendees with skills so that they can actually operate their equipment and do real work to improve their systems. Therefore, adding a field hands-on training component would significantly increase attendees' confidence in applying what they have learned to their own facilities and thus increase the value of the training programs.

\subsection{CERTIFICATION PROGRAMS}

Industrial energy systems professional certifications are summarized in Table 2 . There are a total of 13 certifications for these 8 industrial energy systems. No certifications were found for chilled water systems.

Table 2. Industrial Energy Systems Professional Certifications

\begin{tabular}{|c|c|c|c|c|}
\hline Energy System & Certification & Provider & $\begin{array}{c}\text { ANSI } \\
\text { Accredited }\end{array}$ & $\begin{array}{l}\text { Energy } \\
\text { Efficiency } \\
\text { Focused }\end{array}$ \\
\hline $\begin{array}{c}\text { Compressed Air } \\
\text { System }\end{array}$ & $\begin{array}{l}\text { Qualified AIRMaster+ } \\
\text { Specialist } \\
\end{array}$ & $\begin{array}{l}\text { CAC and } \\
\text { DOE }\end{array}$ & No & Yes \\
\hline \multirow{4}{*}{$\begin{array}{l}\text { Industrial } \\
\text { Refrigeration System }\end{array}$} & $\begin{array}{c}\text { Certified Assistant } \\
\text { Refrigeration Operator }\end{array}$ & RETA & Yes & No \\
\hline & $\begin{array}{c}\text { Certified Industrial } \\
\text { Refrigeration Operator }\end{array}$ & RETA & Yes & No \\
\hline & $\begin{array}{l}\text { Certified Refrigeration } \\
\text { Energy Specialist }\end{array}$ & RETA & No & Yes \\
\hline & $\begin{array}{c}\text { RETA Authorized } \\
\text { Instructor }\end{array}$ & RETA & No & No \\
\hline Chilled Water System & None & $\mathrm{N} / \mathrm{A}$ & $\mathrm{N} / \mathrm{A}$ & $\mathrm{N} / \mathrm{A}$ \\
\hline \multirow[t]{2}{*}{$\begin{array}{l}\text { Process Heating } \\
\text { System }\end{array}$} & $\begin{array}{c}\text { Qualified Process } \\
\text { Heating Assessment and } \\
\text { Survey Tool Specialists }\end{array}$ & DOE & No & Yes \\
\hline & $\begin{array}{c}\text { Chartered Industrial Gas } \\
\text { Consultant }\end{array}$ & GTI & No & No \\
\hline \multirow[b]{2}{*}{ Steam System } & $\begin{array}{c}\text { Qualified Steam Tool } \\
\text { Specialist }\end{array}$ & DOE & No & Yes \\
\hline & $\begin{array}{c}\text { ATMT Certified } \\
\text { Qualified Boiler } \\
\text { Operator }\end{array}$ & $\begin{array}{c}\text { TPC } \\
\text { Trainco }\end{array}$ & No & No \\
\hline $\begin{array}{l}\text { Combine Heat and } \\
\text { Power System }\end{array}$ & $\begin{array}{c}\text { Distributed Generation } \\
\text { Certified Professional }\end{array}$ & AEE & No & No \\
\hline \multirow[t]{2}{*}{ Pump System } & $\begin{array}{c}\text { Qualified Pump System } \\
\text { Assessment Tool } \\
\text { Specialists } \\
\end{array}$ & DOE & No & Yes \\
\hline & $\begin{array}{c}\text { Pump System } \\
\text { Assessment Professional }\end{array}$ & $\mathrm{HI}$ & Intended & Yes \\
\hline Fan System & $\begin{array}{c}\text { Qualified Fan System } \\
\text { Assessment Tool } \\
\text { Specialists } \\
\end{array}$ & DOE & No & Yes \\
\hline
\end{tabular}


The Qualified System Assessment Tool Specialist courses offered by DOE cover five systems (process heating, steam, pump, fan, and compressed air); but they are heavily focused on the use of DOE software tools. The DOE's Better Plants program (https://energy.gov/eere/amo/better-plants) offers industrial companies In-Plant Training sessions which provide hands-on and classroom training on utilizing these software tools. It is worth noting that DOE is currently revamping these software tools and associated training to make them more user friendly, cross-platform compatible, and open-source. The beta version of the pump and process heating system tools is currently available with the remainder to be ready for testing in the next year. For updates on the DOE software tool and training redevelopment efforts, more information can be obtained from: https://energy.gov/AMOTools.

Most certifications are focused on safe equipment operation. CRES by RETA and PSAP by HI are the only ones with a focus on knowledge and skills for optimizing and maintaining system energy performance.

The only certification programs that are ANSI accredited are CARO and CIRO from RETA. PSAP from $\mathrm{HI}$ is intended to be ANSI accredited.

Energy efficiency-focused certification programs for industrial energy systems are needed. Such certifications would enable engineers to more objectively demonstrate their competence on these systems. On the national level, they would help in developing a more qualified and stronger workforce that would continuously improve the energy efficiency of industrial facilities.

ANSI accreditation for personnel certification agencies ensures that the operation of these agencies conforms to the requirements of the International Standards ANSI/ISO/IEC 17024 Conformity Assessment - General Requirements for Bodies Operating Certification of Persons. The ANSI accreditation is recognized nationally and internationally. To ensure these certifications are designed and executed based on high and consistent standards and are internationally recognized, it might be worth considering having all certification programs focused on energy efficiency be ANSI accredited. Doing so could result in these certifications being adopted by other countries and would advance the development of a highly skilled industrial energy system workforce internationally.

\section{CONCLUSIONS}

This paper summarizes currently available training and certification programs for major industrial energy systems to identify the gap between market needs and currently available programs. There is a need to improve training and certification programs for those operating these energy systems and make such programs more widely available. This study reached the following conclusions:

1. There are a great number of training programs for each industrial energy system. Most training programs focus more on operations, maintenance, safety, and design; however, some of these programs briefly discuss the energy performance aspects of these systems.

2. Based on course titles, several training programs may focus on optimizing system energy efficiency; however, limited content information can be found to evaluate those training programs.

3. Qualified System Assessment Tool Specialist courses which are available but no longer actively offered by DOE cover five systems (process heating, steam, pump, fan, and compressed air) and are heavily focused on the use of DOE software tools. The DOE does provide In-Plant Trainings 
which consists of hands-on and classroom training through the Better Plants program; however, this training does not provide certification.

4. The only programs that focus on tool-agnostic knowledge and skills for improving and maintaining energy performance are CRES by RETA and PSAP Certification by HI. Only CARO and CIRO by RETA are ANSI accredited. PSAP by HI is intended to be ANSI accredited.

5. Developing energy efficiency focused training programs that provide a reasonable level of technical depth, hands-on field training, and easily accessible information about the content would fill the gap between market needs and currently available programs.

6. ANSI accredited certification programs focusing on the energy efficiency of industrial energy systems would help in developing a more qualified and stronger national and international workforce. 